\title{
CAMBRIDGE
}

\section{New and Forthcoming Titles!}

Population Genetics for Animal Conservation

Giorgio Bertorelle,

Michael W. Bruford, Heidi C. Hauffe,

Annapaolo Rizzoli,

and Cristiano Vernesi

Conservation Biology

\$140.00: Hb: 978-0-521-86630-9: $410 \mathrm{pp.}$ \$65.00: Pb: 978-0-521-68537-5

\section{Assessing the}

Conservation Value

of Freshwaters

An International Perspective

Edited by Philip J. Boon

and Catherine M. Pringle

Ecology, Biodiversity and Conservation \$135.00: Hb: 978-0-521-84885-5: 304 pp. \$65.00: Pb: 978-0-521-61322-4

\section{Speciation and}

\section{Patterns of Diversity}

Edited by Roger Butlin, Jon Bridle, and Dolph Schluter

\section{Ecological Reviews}

\$140.00: Hb: 978-0-521-88318-4: $346 \mathrm{pp}$. \$63.00: Pb: 978-0-521-70963-7
Second Edition!

Introduction to

Conservation Genetics

Richard Frankham, Jonathan Ballou, and David Briscoe

\$75.00: Pb: 978-0-521-70271-3: 704 pp.

\section{Large-Scale Landscape}

\section{Experiments}

Lessons from Tumut

David B. Lindenmayer

Ecology, Biodiversity and Conservation

\$150.00: Hb: 978-0-521-88156-2: 304 pp.

\$63.00: Pb: 978-0-521-70778-7

\section{Ecology of}

Cities and Towns

A Comparative Approach

Edited by Mark J. McDonnell,

Amy K. Hahs, and Jürgen $\mathrm{H}$. Breuste \$126.00: Hb: 978-0-521-86112-0: $736 \mathrm{pp}$. \$72.00: Pb: 978-0-521-67833-9

\section{Insect Species}

Conservation

T. R. New

Ecology, Biodiversity and Conservation \$150.00: Hb: 978-0-521-51077-6: $272 \mathrm{pp}$. $\$ 69.00: \mathrm{Pb}: 978-0-521-73276-5$

\section{Cold-Water Corals}

The Biology and Geology of Deep-Sea Coral Habitats

J. Murray Roberts, Andrew Wheeler, André Freiwald, and Stephen Cairns \$125.00: Hb: 978-0-521-88485-3: 352 pp.

\section{Cave Biology}

Life in Darkness

\section{Aldemaro Romero}

Ecology, Biodiversity and Conservation \$120.00: Hb: 978-0-521-82846-8: $306 \mathrm{pp}$. $\$ 60.00: \mathrm{Pb}: 978-0-521-53553-3$

\section{Setting Conservation} Targets for Managed Forest Landscapes

Edited by Marc-André Villard and Bengt Gunnar Jonsson

Conservation Biology

\$126.00: Hb: 978-0-521-87709-1: 426 pp. $\$ 63.00: \mathrm{Pb}: 978-0-521-70072-6$

\section{Bird Conservation and Agriculture}

Jeremy D. Wilson, Andrew D. Evans, and Philip V. Grice

Ecology, Biodiversity and Conservation \$135.00: Hb: 978-0-521-57181-4: 404 pp. \$63.00: Pb: 978-0-521-73472-1

Prices subject to change.
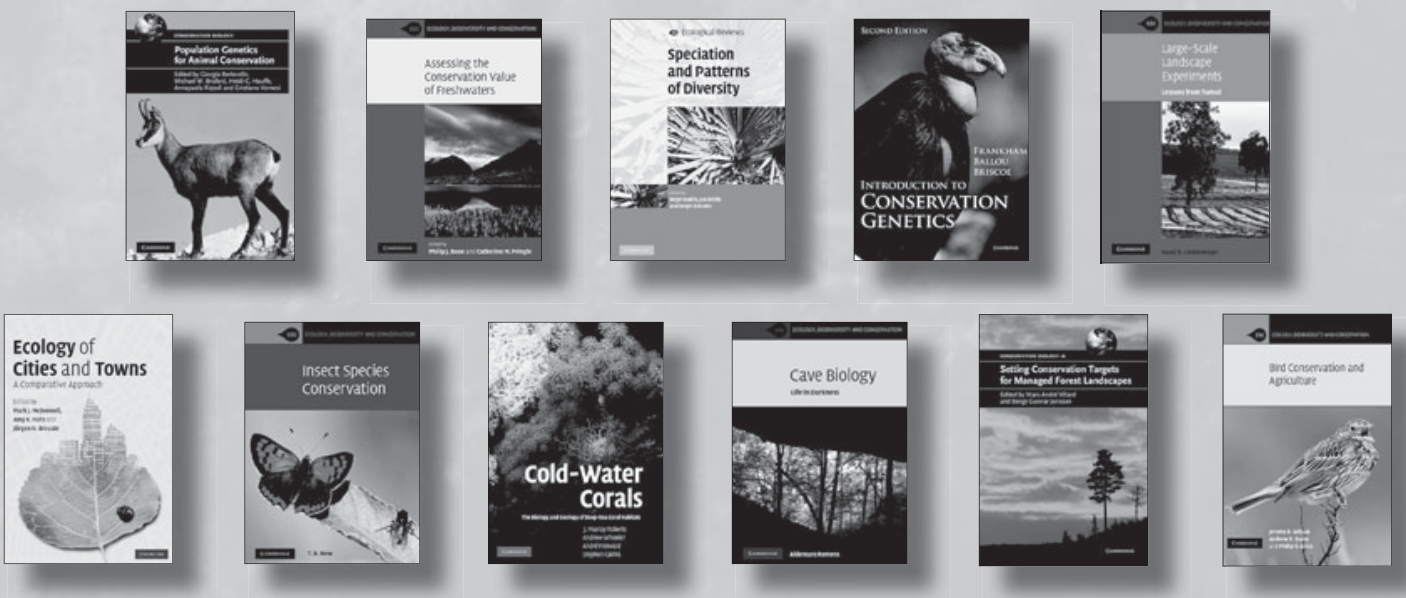


\section{CAMBRIDGE J JUNALS}

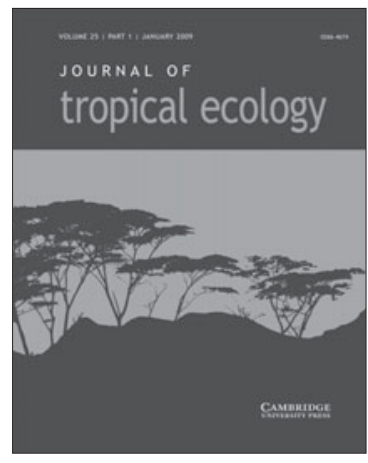

Journal of Tropical Ecology

is available online at

http:/ljournals.cambridge.org/tro

To subscribe contact Customer Services

in Cambridge:

Phone +44 (0)1223 326070

$\mathrm{Fax}+44(0) 1223325150$

Email journals@cambridge.org

in New York:

Phone $+1(845) 3537500$

$\mathrm{Fax}+1$ (845) 3534141

Email

subscriptions_newyork@cambridge.org

\section{Journal of Tropical Ecology}

\section{Editor}

Ian Turner, Winchelsea, UK

Journal of Tropical Ecology publishes papers in the important and now established field of the ecology of tropical regions, either arising from original research (experimental or descriptive) or forming significant reviews. The journal provides a platform for the dissemination of information on all aspects of tropical communities and ecosystems.

Price information is available at http://journals.cambridge.org/tro

\section{Free email alerts}

Keep up-to-date with new material - sign up at http://journals.cambridge.org/alerts 


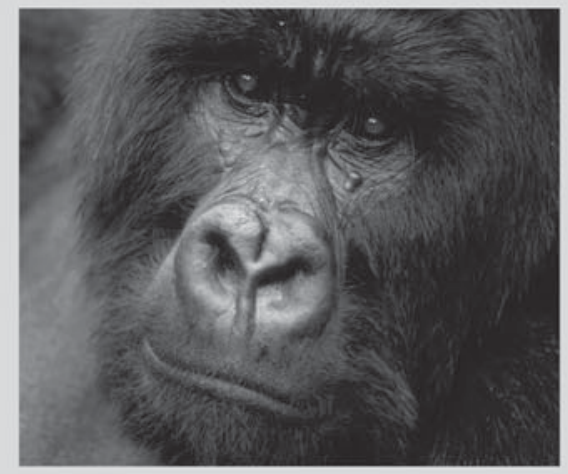

\section{THE FLAGSHIP SPECIES FUND}

Launched in 2001, FFl's Flagship Species Fund has provided almost $£ 1$ million to protect 56 'charismatic' species - species that have important ecological roles and whose protection helps conserve other plants and animals living in the same habitats. These include mountain gorillas, spider monkeys, marine turtles, Cao Vit gibbons, Siamese crocodiles, Irrawaddy dolphins, snow leopards, cheetahs, Sumatran tigers and many others.

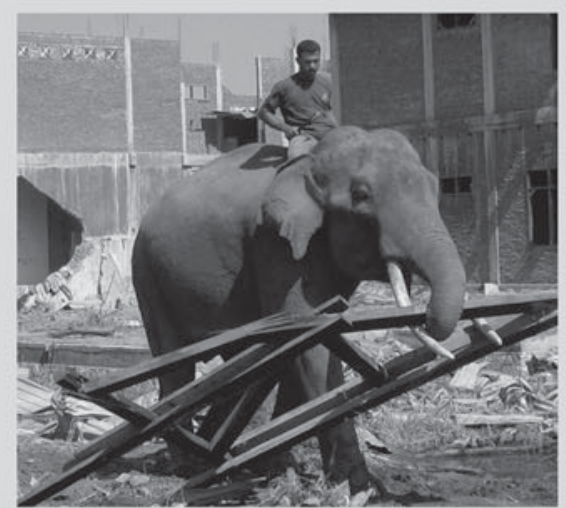

EMERGENCY RESPONSE

$\mathrm{FFI}$ was the only international conservation organisation to help coordinate the immediate emergency response to the Indian Ocean Tsunami in Aceh, Sumatra, in December 2004. $\mathrm{FFI}$ has been working in Aceh since 1998, and was able to help where other organisations could not. FFI has developed a post disaster programme, helping to secure a multi-donor grant of US\$17.6 million for forest protection.

Fauna \& Flora International, Jupiter House, 4th Floor, Station Road, Cambridge, CB1 2JD, UK. $\mathrm{Tel}+44(0) 1223571000$ Fax +44 (0) 1223461481 Email: info@fauna-flora.org
FFl works in over 40

countries, and is involved in more than 180 projects. Here are a few of them...

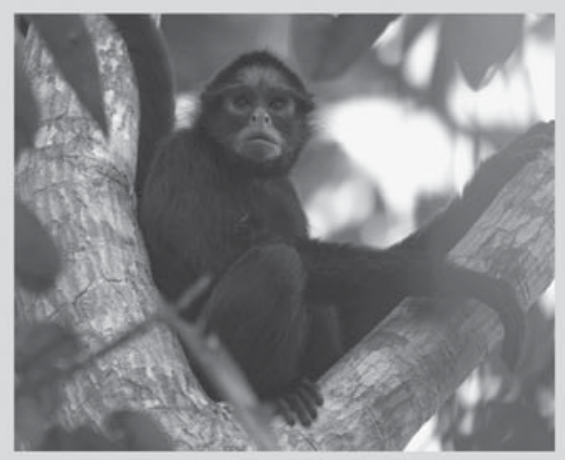

HALTING DEFORESTATION

Working on the front line in the battle against deforestation in Ecuador, FFI has been instrumental in protecting a strip of forest known as the 'Awacachi Corridor', alongside our local partner. By linking two existing nature reserves via this corridor, we've vastly increased its conservation value. Now we must work to reinforce the corridor at the points where it is most vulnerable to logging and conversion to palm oil plantations. Raising the funds necessary to achieve this will be crucial to the project's success.

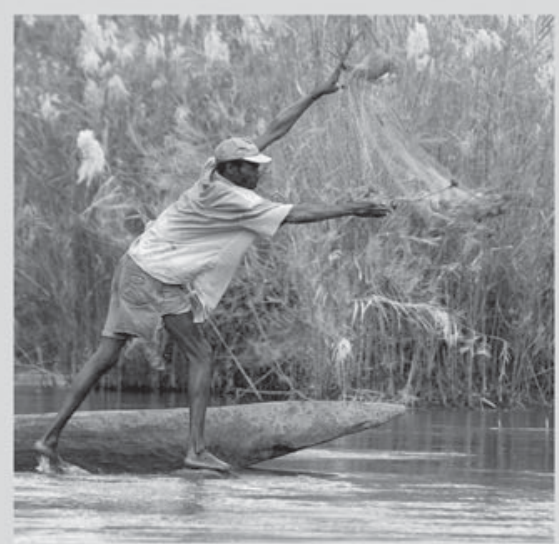

BIODIVERSITY \& HUMAN NEEDS

$\mathrm{FFI}$ wants to ensure that conservation and rural livelihoods are compatible. In the vast Niassa Reserve in Mozambique we helped develop policies that gave the 20,000 reserve residents a say in how the Reserve is managed and used, to protect their rights and traditional practices. In Liberia we helped to draft national legislation that incorporated community interests into forest land use planning.
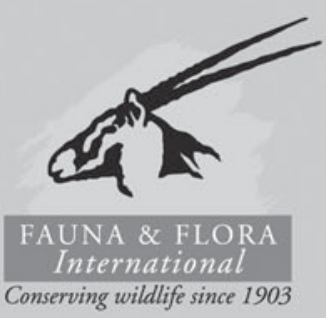

Fauna \& Flora International is the world's longest established conservation organisation, founded in 1903. We work to conserve threatened species worldwide, choosing solutions that are sustainable, based on sound science and take account of human needs.

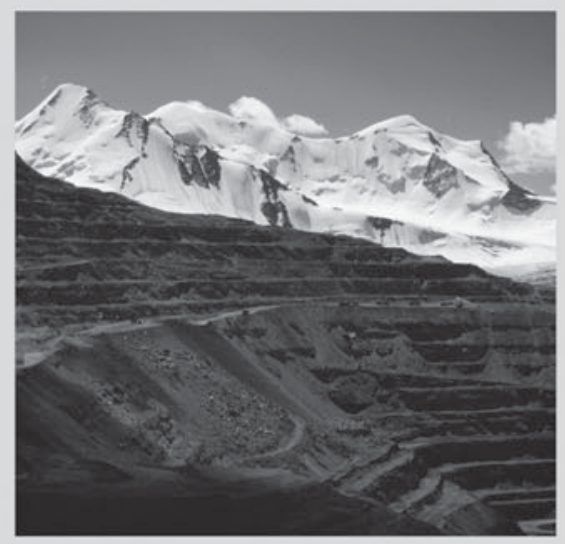

BUSINESS AND BIODIVERSITY

$\mathrm{FFI}$ works with the private sector to try to ensure that business activities are not undertaken at the expense of biodiversity. We believe that constructive engagement is key to influencing the environmental policies and practices of business and achieving sustainable development. Our approach involves working with the private sector to enable it to understand and manage its impacts on biodiversity.

We need your support to protect the world's threatened species and ecosystems worldwide.

www.fauna-flora.org 


\section{Oryx Centenary Archive 1903-2003 Available on both CD and DVD}

No. 1

\section{Invaluable arch
and research tool}

Members of Fauna \& Flora International: $\mathbf{4} 49$

New members:

f99

Special price for CD-ROM + annual membership of Fauna \& Flora International. Institutions in developing countries, contact Oryx Centenary CD at address below.

Institutions: $\mathbf{f 5 9 5}$

All prices include VAT and shipping. Requires Windows 98 or later operating systems

Payment is also accepted in Euro or USD; contact Editorial Office for details

Methods of payment:

\section{FFI membership plus} CD-ROM special offer

\section{$\square$ Cheque/postal order made out to}

Fauna \& Flora International (currency: pounds sterling only)

I enclose $\mathrm{f}$ :

$\square$ Credit Card: $\square$ American Express $\square$ Visa $\square$ Delta $\square$ Switch ${ }^{*} \square$ Mastercard $\square$ Eurocard

Name of card holder:

Card Number:
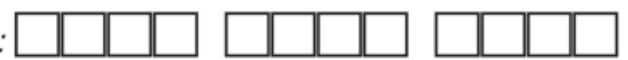

Start date:

Expiry date:

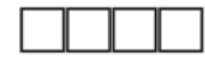

*Issue No. (Switch only):

vown

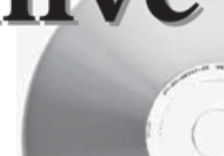

Three-digit security number (on back of card):

$\square$ CD (3 disks) $\quad \square$ DVD (1 disk)

Name \& Address:

Send orders to: Oryx Centenary CD, Fauna \& Flora International, 4th Floor, Jupiter House, Station Road, Cambridge, CB1 2JD, UK. E-mail enquiries: oryx@fauna-flora.org 


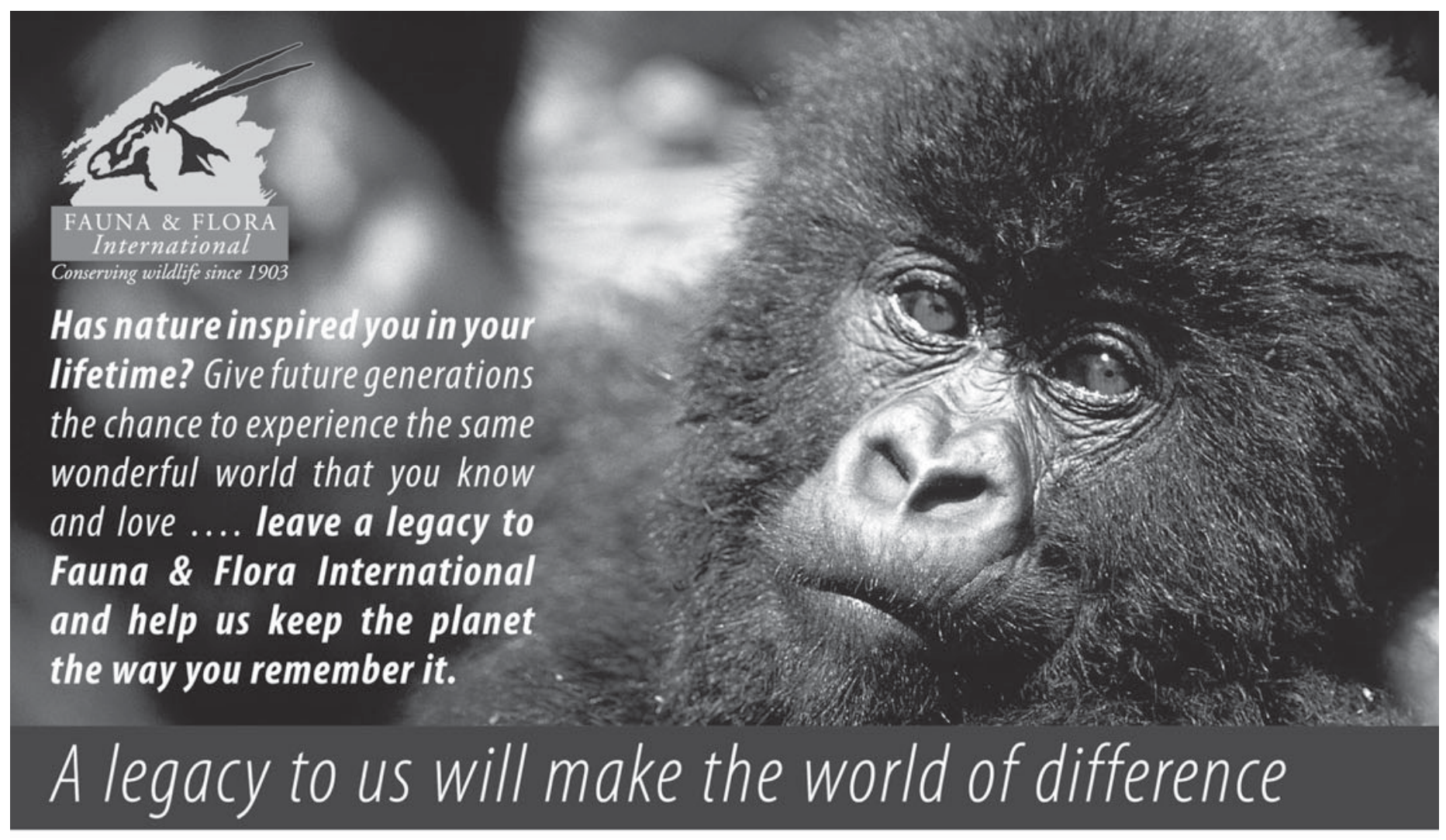

\section{There can be no more positive act than that of preserving the planet.}

Imagine a planet where the orangutan or the tiger are merely remote references in a text book or where natural history programmes feature only footage of animals kept in captivity because there are too few in the wild to film. This could be the future planet that your grandchildren live in.

The list of species on the brink of extinction has reached unprecedented levels. Habitat loss, overhunting, and many other threats are destroying the earth's ecosystems, and climate change may push some already endangered species over the edge. We need to act now to save the planet's wild animals and wild places if we want future generations to enjoy them as we do.

FFI is committed to raising funds to conserve life on Earth, and we are entirely reliant upon subscriptions, donations, grants and legacies to do this. In the face of today's immense environmental challenges, donations in the form of legacies are amongst our greatest chances to fulfil our aims.

Please consider leaving FFI a Gift in your Will. Of course you will want to make provision for your family and close friends first; we only ask that you consider leaving a share of what is left to the conservation of the planet through FFl's work.

You can learn more about how to help FFI in your Will from our website at:

www.fauna-flora.org/legacies.php or call Milly on $+44(0) 1223579018$ for a personal chat.

A Gift in your Will is a simple but effective way for you to make a huge difference to the world you leave for your family.

For further information, e-mail us at camila.iturra@fauna-flora.org Alternatively contact Milly at: Fauna \& Flora International, Jupiter House, 4th Floor, Station Road, Cambridge, CB1 2JD.

Tel: +44 (0)1223 579018 Fax: +44 (0)1223 461481. www.fauna-flora.org

Established in 1903. A Company limited by Guarantee, Registered in England Number 2677068.

Registered Charity Number 1011102. Photos @ Juan Pablo Moreiras / FFI 
Fauna \& Flora International membership application (Please complete in block letters)

Surname

First name(s)

Title

Address

Postcode

E-mail address

Membership $\square$ Concessionary (senior citizen, unwaged, student*, includes Oryx and Fauna \& Flora, FFl's magazine) $£ 40$ categories

(tick appropriate box)

$\square$ Sponsor (includes additional subscription for Oryx in a developing country) $€ \mathbf{I} 25$

$\square$ Supporter (includes Fauna \& Flora) $£ 35 \quad \square$ Life $£ \mid 500$

$\square$ Oryx (includes Oryx and Fauna \& Flora) $€ 75$

Payment is also accepted in Euro or USD; contact the Membership

Secretary for details

*If student please give date you expect to finish studies

\section{Methods of}

Cheque/postal order (currency: pounds sterling only)

I enclose $t$

payment

Credit Card (state American Express, Visa, Delta, Switch*, Mastercard, CAF, Eurocard)

Name of card holder

Expiry date

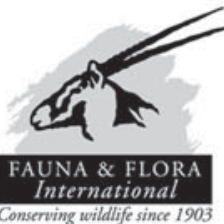

Card Number
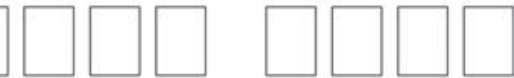

Valid from

Three-digit security number (on back of card)

*If paying by Switch, please state issue number

FOR UK BANK ACCOUNT HOLDERS ONLY

Direct Debit (Please fill in the whole form and send it to FFI)

I. Name and full postal address of your Bank or Buiding Society branch

Originator's identification number 916890

To:The Manager
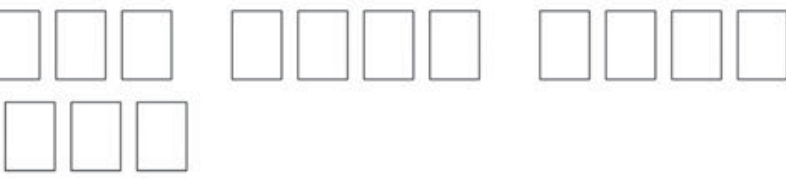

Address

Postcode

2. Name(s) of account holder(s)

3. Branch Sort Code
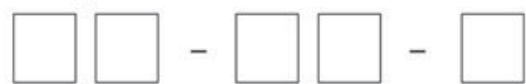

4. Bank or Building Society account No.

5. FFI ref. no. (office use only)

6. Instructions to your Bank or Buiding Society. Please pay Fauna \& Flora International Direct Debits from the account detailed on this instruction subject to safeguards assured by The Direct Debit Guarantee

Signature(s)

Date

FOR UK TAX PAYERS ONLY

Gift Aid Declaration
I would like my subscription payment and any donations to Fauna \& Flora International

to be eligible for Gift Aid. I will be paying an amount of income tax and/or capital gains tax at least equal to the tax that Fauna \& Flora International reclaims on my subscription in each tax year.
Name

Address

Signature Postcode_ Date $\quad$ Dafo of

membership

application to:

Membership Secretary, Fauna \& Flora International, 4th Floor, Jupiter House, Station Road, Cambridge CBI 2JD, UK

\begin{tabular}{|c|c|}
\hline $\begin{array}{l}\text { The } \\
\text { Direct Debit } \\
\text { Guarantee } \\
\text { This guarantee should } \\
\text { be detached and } \\
\text { retained by the Payer }\end{array}$ & $\begin{array}{l}\text { This Guarantee is offered by all Banks and Building Societies that take part in the } \\
\text { Direct Debit Scheme. The efficiency and security of the scheme is monitored and } \\
\text { protected by your own Bank or Building Society. } \\
\text { If the amounts to be paid or the payment date changes, Fauna \& Flora International will notify you I4 days in } \\
\text { advance of your account being debited or as otherwise agreed. } \\
\text { If an error is made by FAUNA \& FLORA INTERNATIONAL or by your Bank or Building Society, you are } \\
\text { guaranteed a full and immediate refund from your branch of the amount paid. } \\
\text { You can cancel a Direct Debit at any time by writing to your Bank or Building Society. Please also send a copy } \\
\text { of your letter to us so that we can alter our records. }\end{array}$ \\
\hline
\end{tabular}




\section{Instructions for Contributors}

Oryx-The International Journal of Conservation, published quarterly on behalf of Fauna \& Flora International, is a journal of biodiversity conservation, conservation policy and sustainable use, and the interactions of these with social, economic and political issues. The journal has a particular interest in material with the potential to improve conservation management and practice. Oryx also supports the publishing and communication aspirations of conservation practitioners and researchers worldwide, and helps build capacity for conservation.

Articles (2,000-7,000 words), Reviews ( $<7,000$ words), Forum paper $(<4,000$ words) and Short Communications ( $<2,000$ words) are invited on topics relevant to the journal's focus, including:

- The nature and results of conservation initiatives, including case studies - Research on the sustainable use of wild species

- Research on the status of threatened species, taxonomic groups or habitats

- Reviews of conservation policy, strategy and legislation in practice

- Planning for species and biodiversity conservation

- The working of international conservation conventions

- The history of conservation, including the role of key people, organizations and initiatives

- The causes and consequences of biodiversity loss

- Case studies of conservation projects and programmes

- The social, economic and political dimensions of conservation

Reviews provide comprehensive overviews of a particular conservation topic Forum papers promote debate about current and controversial issues, with critical responses commissioned from one or more authors. Articles on the status of threatened species, taxonomic groups or habitats should generally be $<4,500$ words and have, where relevant, a context beyond that of the subject studied.

Submission Online at http://mc.manuscriptcentral.com/oryx (see http://www. oryxthejournal.org for further advice). Upon submission the Corresponding Author must confirm that: (1) the submitted manuscript has not been published or submitted for publication elsewhere, (2) all authors have read the submitted manuscript and agreed to its submission, and (3) all authors have abided by the Code of Conduct for authors contributing articles (see Oryx 35, 99-100 or http://www.oryxthejournal.org). If there is overlap with other articles, including any in press or in preparation, this should be stated and the articles in question sent to the Editor. Both quantitative and qualitative methodology used in the reported work should be appropriate to the research question and must be clearly described. Management recommendations should be made where appropriate, and details of any implementation provided. Dates of any fieldwork must be provided and, other than long-term studies, submissions with data $>4$ years old will not normally be considered.

Preparation of manuscripts Consult a recent issue of Oryx for general style. Contributions should be in English, with British English spelling and terminology, double-spaced, without footnotes, and with line numbers. Submissions, which can be a single file with all Tables, Figures, Plates and Appendices at the end or with text and other elements in separate files, must be in DOC forma (not PDF). For submission, graphics can be in low to medium resolution as long as they are legible, with publication-quality graphics to be provided upon any final acceptance. Cover page should contain title, word count (all inclusive excep for Tables and Figure and Plate legends), and full mailing address, e-mail, and address at the time the research was carried out, if different, of the corresponding author and all additional authors. Pages to be numbered, and order of sections to be: cover page, main text, biographical sketches, Tables, Figure and Plate legends, Figures, Plates. Short Communications must not have any subheadings.

Title A succinct description of the work ( $\leq 20$ words) preferably embodying either the aim or the overall conclusion.

Abstract In $<250$ words, the aims, methods, major findings and conclusions should be informative without reference to the text and should not contain any references or undefined abbreviations.

Keywords Up to eight pertinent words or phrases, in alphabetical order.

Structure Articles should generally follow the Introduction, Study Area (where appropriate), Methods, Results and Discussion format. Minimize use of other subheadings.

References Cited in the text as, for example, Hardcastle \& Wilson (1996) or (Leadbeater, 1996). For three or more authors use the first author's surname followed by et al. Multiple references to be in chronological order. Reference list should be in alphabetical order, and article titles and the titles of seria publications to be given in full. If citations and bibliography are prepared using a bibliography manager any field codes, tags or similar must be removed. The following are examples of Oryx style:

Beck, B.B., Rapaport, L.G. \& Stanley Price, M.R. (1994) Reintroduction of captive-born animals. In Creative Conservation: Interactive Management of Wild and Captive Animals (eds P.J.S. Olney, G.M. Mace \& A.T.C. Feistner), pp. 265-286. Chapman \& Hall, London, UK.

Bowler, M. (1991) Implications of large predator management on commer cial ranchland in Zimbabwe. MSc thesis, University of Zimbabwe, Harare, Zimbabwe.
Brady, L.D., Huston, K., Jenkins, R.K.B., Kauffmann, J.L.D., Rabearivony, J., Raveloson, G. \& Rowcliffe, M. (1996) UEA Madagascar Expedition '93. Unpublished Report. University of East Anglia, Norwich, UK.

IUCN (2008) 2008 IUCN Red List of Threatened Species. IUCN, Gland, Switzerland. Http://www.iucnredlist.org [accessed 24 July 2008].

LeBoeuf, B.J., Kenyon, K.W. \& Villa-Ramirez, B. (1986) The Caribbean monk seal is extinct. Marine Mammal Science, 2, 70-72.

MacArthur, R.H. \& Wilson, E.O. (1967) The Theory of Island Biogeography. Princeton University Press, Princeton, USA.

Sutherland, W.J. (ed.) (1998) Conservation Science and Action. Blackwell Science, Oxford, UK

Biographical sketches The research interests of all authors ( $<150$ words total), over and above what is obvious from the subject of the manuscript and the authors' affiliations.

Tables Each on a separate page, with captions that are comprehensible without reference to the text.

Figures \& Plates Guidelines for the preparation of Figures and Plates are at http://www.oryxthejournal.org

Appendices For mathematical or statistical models, lengthy tables, and questionnaires. May be published online-only, depending on length. Online-only appendices can also include Figures and Plates, and these can be in colour.

Abbreviations Minimize use, and provide full expansion of any at first mention in the text.

Symbols, units \& currencies Use SI units (International System of Units, http://www.bipm.org/en/si/) and ISO 4217 currency codes (http://www.iso. org/iso/support/faqs/faqs_widely_used_standards/widely_used_standards_ other/currency_codes/currency_codes_list-1.htm).

Nomenclature Where necessary, provide the basis used for nomenclature of taxa. The first time a species is mentioned its scientific name should follow without intervening punctuation, thus African elephant Loxodonta africana. English names should be in lower case throughout except when they incorporate a proper name.

Offprints, page charges \& colour figures Contributors receive a PDF file of their article, and may purchase additional hard copy offprints. No page charges are levied. Colour Figures can be published but only at the author's expense.

Copyright Authors will be asked, upon acceptance of an article, to transfer copyright to Fauna \& Flora International.

Review Manuscripts are subject to rigorous peer review. Contributors may suggest appropriate reviewers. For manuscripts with a substantial statisti$\mathrm{cal}$ content, one of the reviewers will be a statistician. The main criteria for acceptance are originality, scientific rigour, an appropriately broad context, relevance to the readership and acceptability of style. We receive more submissions than we are able to publish and the final authority in all matters relating to publication lies with the Editor

Proofs Sent to authors as a PDF file (free viewer available from http://www adobe.com). Corrected proofs must be returned to the Editor within 3 days of receipt; minor corrections can be communicated by e-mail.

The Editor welcomes contributions to the other sections of the journal (deadlines for the January, April, July and October issues are 1 October, 1 January, 1 April and 1 July, respectively), by e-mail to oryx@fauna-flora.org (see http://www.oryxthejournal.org for further advice).

Letters Substantial and informative contributions ( $<700$ words) in response to material published in the journal.

Briefly News ( $<6$ months old) of general conservation interest based on authoritative published sources ( $<150$ words), including reputable web sites.

Conservation news Major recent developments ( $<6$ months old) in conservation or important announcements ( $<700$ words), other than from published sources.

Grants \& Opportunities, Meetings and Publications Availability of grants or funding opportunities, meeting announcements and book reviews, respectively. Authors and publishers are invited to send publications to the Editor for potential review.

These Instructions for Contributors (including the Guidelines for preparation of Figures \& Plates and the Code of Conduct for authors contributing articles) are available on the Oryx web site (http://www.oryxthejournal.org), from Cambridge University Press (http://journals.cambridge.org/orx), or from the Editor, Oryx - The International Journal of Conservation, Fauna \& Flora International, 4th Floor, Jupiter House, Station Road, Cambridge, CB1 2JD, UK; E-mail oryx@fauna-flora.org; Tel. +44 (0)1223 571000; Fax +44 (0)1223 461481 .

Oryx is covered by Biological Abstracts, BIOBASE/Current Awareness in Biological Sciences, Current Contents Agriculture, Biology and Environmental Science, Science Citation Index, SciSearch, Research Alert and Ecology Abstracts. 
4492010 and all that-looking forward to biodiversity conservation in 2011 and beyond, Martin Fisher

451 Briefly

461 Conservation news

\section{Conservation planning}

464 Approaches to landscape- and seascape-scale conservation planning: convergence, contrasts and challenges, Robert $L$. Pressey and Madeleine C. Bottrill

476 The Landscape Species Approach: spatially-explicit conservation planning applied in the Adirondacks, USA, and San Guillermo-Laguna Brava, Argentina, landscapes, Karl A. Didier, Michale J. Glennon, Andrés Novaro, Eric W. Sanderson, Samantha Strindberg, Susan Walker and Sebástian Di Martino

488 Designing a resilient network of marine protected areas for Kimbe Bay, Papua New Guinea, Alison Green, Scott E. Smith, Geoff Lipsett-Moore, Craig Groves, Nate Peterson, Stu Sheppard, Paul Lokani, Richard Hamilton, Jeanine Almany, Joseph Aitsi and Leo Bualia

499 Landscape-scale spatial planning at WWF: a variety of approaches, John Morrison, Colby Loucks, Barney Long and Eric Wikramanayake

508 The Heartland Conservation Process: enhancing biodiversity conservation and livelihoods through landscape-scale conservation planning in Africa, Adam Henson, David Williams, Jef Dupain, Helen Gichohi and Philip Muruthi

520 Advancing the case for microbial conservation, Charles $S$. Cockell and Harriet L. Jones

527 Short Communication Preserving pathogens for wildlife conservation: a case for action on amphibian declines, Jamie Voyles, Scott D. Cashins, Erica Bree Rosenblum and Robert Puschendorf

530 Direct payments for biodiversity conservation in developing countries: practical insights for design and implementation, Sarah Milne and Eduard Niesten

542 The Djibouti francolin and juniper forest in Djibouti: the need for both ecosystem and species-specific conservation, Zomo S.Y. Fisher, Samantha Cartwright, Clive Bealey, Houssein A. Rayaleh, Philip McGowan and E.J. Milner-Gulland

552 Short Communication The population size and distribution of the Vulnerable beira antelope Dorcatragus megalotis in Djibouti, Nina Giotto, Daher Obsieh, Jean Joachim and Jean-François Gerard

556 Nesting estimation and analysis of threats for Critically Endangered leatherback Dermochelys coriacea and Endangered olive ridley Lepidochelys olivacea marine turtles nesting in Congo, Marie-Clélia Godgenger, Nathalie Bréheret, Gaëlle Bal, Karine N'Damité, Alexandre Girard and Marc Girondot

564 Short Communication The influence of landscape characteristics and anthropogenic factors on waterhole use by Vulnerable Nubian ibex Capra nubiana, Omar Attum, Sayed K. El Noby and Ibrahim N. Hassan

568 A review of historical trends in the distribution and abundance of elephants Loxodonta africana in Mozambique, C.P. Ntumi, S.M. Ferreira and R.J. van Aarde
580 Same-site multiple releases of translocated white rhinoceroses Ceratotherium simum may increase the risk of unwanted dispersal, Ole-Gunnar Støen, Mompoloki Lettie Pitlagano and Stein R. Moe

586 Impact of human disturbance and beliefs on the tree agama Acanthocercus atricollis atricollis in a South African communal settlement, Martin J. Whiting, Kinesh Chetty, Wayne Twine and Pau Carazo

591 Population abundance and apparent survival of the Vulnerable whale shark Rhincodon typus in the Seychelles aggregation, David Rowat, Conrad W. Speed, Mark G. Meekan, Mauvis A. Gore and Corey J.A. Bradshaw

599 Rapid degradation of a Mauritian rainforest following 60 years of plant invasion, Malika Virah-Sawmy, John Mauremootoo, Doreen Marie, Saoud Motala and JeanClaude Sevathian

608 Do fruit bats deserve to be listed as vermin in the Indian Wildlife (Protection) \& Amended Acts? A critical review, Natarajan Singaravelan, Ganapathy Marimuthu and Paul A. Racey

614 Short Communication Is a forest road a barrier for the Vulnerable Cabot's tragopan Tragopan caboti in Wuyishan, Jiangxi, China? Yue Sun, Lu Dong, Yanyun Zhang, Guangmei Zheng and Stephen J. Browne

618 Status and distribution of the Endangered banteng Bos javanicus birmanicus in Vietnam: a conservation tragedy, Miguel Pedrono, Ha Minh Tuan, Philippe Chouteau and Frédéric Vallejo

626 The diversity, status and conservation of small carnivores in a montane tropical forest in northern Laos, Arlyne Johnson, Chanthavy Vongkhamheng and Thavisouk Saithongdam

634 Assessing the Sumatran tiger Panthera tigris sumatrae population in Batang Gadis National Park, a new protected area in Indonesia, Hariyo T. Wibisono, Joe J. Figel, Sugesti M. Arif, Anton Ario and Abu H. Lubis

639 Movements of translocated captive-bred and released Critically Endangered kaki (black stilts) Himantopus novaezelandiae and the value of long-term post-release monitoring, Yolanda van Heezik, Richard F. Maloney and Philip J. Seddon

648 Have Patagonian waterfowl been affected by the introduction of the American mink Mustela vison? Salvador J. Peris, Javier Sanguinetti and Moisés Pescador

655 Publications

656 Meetings

657 Acknowledgements

658 Erratum

Cover Identifying individuals through time can provide valuable ecological information. A combination of photoidentification and marker tagging of Vulnerable whale sharks Rhincodon typus at an aggregation in the Seychelles suggests a highly transient population for which international or at least regional-scale conservation approaches are required. For further details see pages 591-598. (Photograph @) Andy Murch/elasmodiver.com).

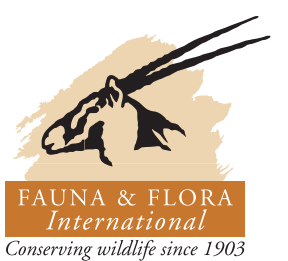

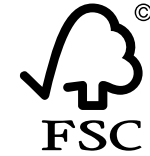
๑) 1996 Forest Stewardship Council
Supported by

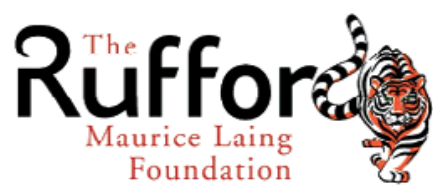

